\title{
PRESSUPOSTOS CONSTITUCIONAIS DO DIREITO EMPRESARIAL: ANÁLISE DOS REGISTROS EMPRESARIAIS E DO SISTEMA DE DEFESA DA CONCORRÊNCIA.
}

\author{
Marcos Wachowicz ${ }^{1}$
}

\section{RESUMO}

O presente artigo aborda a atividade empresarial realizada pela Sociedade Empresária ou Empresário Individual enquanto agente econômico cuja atuação é regulada pelos órgãos públicos: Juntas Comerciais, Departamento Nacional de Registros Mercantis e o Conselho Administrativo de Defesa Econômica. Nesta perspectiva serão analisados os pressupostos constitucionais que norteiam a atividade econômica empresarial, que estão subjacentes ao sistema de defesa da concorrência.

Palavras-chave: Direito Empresarial Defesa da Concorrência. Ordem Econômica.

\section{SUMÁRIO}

1. Introdução. 1.1 A atuação das Juntas Comerciais e a competência do DNRC. 1.2 Atos registrais da Junta Comercial. 1.3 Processo de Registro perante a Junta Comercial 2. A Atividade empresarial e as Constituições brasileiras. 2.1. Os pressupostos constitucionais do Direito Empresarial. 2.2. A proteção da Ordem Econômica e da Concorrência. 3. A defesa da concorrência no Brasil. 3.1. Do abuso do Poder Econômico. 3.1. Do Conselho Administrativo de Defesa Econômica - CADE. 3.2. Da natureza jurídica das decisões do CADE. A) A questão do caráter vinculado ou discriscionário do ato. B) A questão dos conceitos indeterminados e da regulação técnica. 3.3. Os Princípios Jurídicos-administrativos aplicáveis no controle judicial das decisões do CADE. 4. O caráter altamente interdisciplinar do direito de concorrência. 5. REFERÊNCIAS.

\section{INTRODUÇÃO}

Este trabalho analisa os registros públicos de interesse dos empresários mercantis, mais especificamente no que tange aos usos e constumes mercantis como fontes do direito mercantil com as normas aplicáveis de Direito Comercial e Concorrêncial.

O Direito Comercial está intimamente ligado à atividade econômica, sendo perfeitamente admissível a percepção da sociedade empresária e/ou empresário individual como sendo um agente econômmico cuja atividade está sujeita aos princípios constituicionais que regem a ordem econômica do Estado brasileiro. As dificuldades surgem da confusão entre atividade econômica 
empresarial com o Direito Econômico, ou ainda com o Direito Comercial e o Direito Civil. Almicar Dougras Packer ${ }^{2}$ aponta neste sentido, "a discriminação do domínio de cada um desdes diferentes ramos do Direito se torna simples, desde o momento em que atentamos devidamente para a natureza das instituições que eles envolvem. Uma coisa é a propriedade (Direito Civil), outra o exercício da liberdade contratual (Direito Comercial), outra, finalmente, são as restrições impostas ao exercício desta liberdade (Direito Econômico).

A sociedade empresarial atualmente é sem dúvida, no direito brasileiro, entendida e regulada enquanto agente econômico. Isto, na medida em que, a própria empresa é definida como uma atividade econômica organizada que conjuga capital, trabalho e tecnologia com finalidade lucrativa, recebendo assim, uma tutela jurídica específica na Constituição Federal de 1988, no Capítulo sobre a Ordem Econômica a partir do artigo 170, que estabelece os princípios constitucionais que norteiam a atividade empresarial.

Neste sentido, a atuação dos órgãos públicos responsáveis pelos atos registrais de formação regular da sociedade empresária e de coleta dos usos e costumes mercantis também estão sujeitos em suas praxes de assento de práticas comerciais aos ditames constitucionais.

Para haja a formação regular da atividade empresarial a primeira obrigação que se apresenta ao empresário para o exercício regular de sua atividade é submeter os atos constitutivos no registro perante a Junta Comercial da sede de seu estabelecimento. Isto antes do início da exploração de seu negócio, conforme dispõe o artigo 976 e 1.150 do Código Civil, de conformidade com a Lei 8.934, de 18 de Novembro de 1994, regulamentada pelo Decreto $\mathrm{n}^{\circ}$. 1.800, de 30 de Janeiro de 1996, reviu toda a matéria, dispondo sobre o Registro Público de Empresas Mercantis.

A Lei 8.934/94 que regula sobre o Registro Público das Empresas estabeleceu dois níveis de competência: (i) a primeira esfera de competência estadual está a cargo da Junta Comercial existente em cada unidade da federação, e, (ii) numa segunda esfera aglutinadora com atuação e competência nacional esta o Departamento Nacional de Registro do ComércioDNRC.

\subsection{A atuação das juntas comerciais e a competência do dnrc}

O Departamento Nacional de Registro do Comércio-DNRC é órgão vinculado ao Ministério do Desenvolvimento, Indústria e Comércio Exterior tendo como finalidade fixar diretrizes gerais para a prática de atos registrários a serem realizados pelas Juntas Comerciais Estaduais, acompanhando sua aplicação e corrigindo distorções.

Frise-se o DNRC não tem função executiva, não realiza qualquer refistro, antes possui as seguintes competências:

(i) supervisionar e/ou coordenar a execução do registro de empresas, expedindo normas e instruções dirigidas às Juntas Comerciais de todo o país; 
(ii) orientar e/ou fiscalizar as Juntas Comerciais, zelando pela regularidade dos registros de empresas;

(iii) promover medidas correcionais do Registro de Empresa, derivando daí o poder de intervir nos serviços da Junta Comercial,

(iv) organizar e manter atualizado o Cadastro Nacional das Empresas Mercantis. Trata-se de banco de dados estatísticos que serve de subsídio à política econômica federal.

( $v)$

De outra parte as Juntas Comerciais são órgãos vinculados diretamente à administração pública estadual, cabendo-Ihes a execução do registro da empresa, não lhes competindo negar a prática do ato registral senão com fundamento em vício de forma, sempre sanável.

Assim decorre que a subordinação hierárquica das Juntas para com o DNRC é somente no tocante a questões de Direito Comercial, por outro lado, no tocante a questões de Direito Administrativo e Financeiro está subordinada ao Poder Executivo Estadual. A Junta Comercial possui as seguintes competências:

(i) assentamentos dos usos e práticas mercantis: O Comércio rege-se por normas advindas do costume que após ampla discussão no meio empresarial, análise e adequação à ordem jurídica vigente pela Procuradoria, serão assentados em livros próprios, cabendo à Junta expedir aos interessados as correspondentes certidões, que podem servir em juízo como início de prova;

(ii) habilitação e nomeação de tradutores públicos e interpretes comerciais: A Junta funciona como órgão profissional dessas categorias para comerciais, cabendo-Ihe exercer o poder disciplinar, o código de ética da atividade e controle do exercício da profissão;

(iii) expedição da carteira de exercício profissional do comerciante e demais pessoas legalmente inscritas no registro de empresa.

A importância da atuação dos órgão públicos responsáveis pelos atos registrais de tutela e assentamentos dos usos e práticas mercantis é ainda maior por ser fonte do direito comercial. Isto porque, o Direito Comercial utiliza o método indutivo para criação da norma que regem a atividade empresarial. Já o Direito Civil, diversamente, utiliza o método dedutivo para a criação da norma, partindo da análise geral do comportamento humano na sociedade, para regurar relações específicas individuais como a exemplo do divórcio no Direito de Família. 
Com efeito, é a prática empresarial que irá induzir a criação de normas, exemplo disto se observa na prática comercial atual e amplamente difundida do comércio eletrônico, a qual se estabeleceu mundialmente pela INTERNET sem que houvesse prévio regramento legislativo.

É preciso ter-se claro que nenhuma prática comercial poderá ser admitida como fonte do direito comercial se esta for contrária a lei, isto se opera pela aplicação do princípio da legalidade que está presente do direito comercial.

\subsection{Atos registrais da junta comercial}

A Lei 8.934 de 1994 estabeleceu três atos para o registro praticados pelas Juntas Comerciais Estaduais: (i) a matrícula, (ii) o arquivamento, e a (iii) autenticação.

A matrícula é o ato de inscrição na Junta Comercial de atividades paracomerciais. Exemplo: dos tradutores públicos, intérpretes comerciais que são habilitados e nomeados pela Junta; e os leiloeiros, trapicheiros e administradores de armazéns gerais são apenas matriculados.

O arquivamento é o ato de inscrição do Comerciante individual na Junta Comercial, bem como os atos de constituição, alteração e dissolução das sociedades mercantis. Exemplificando: cooperativas, sociedades civis, consórcios de empresas, grupos de sociedades, microempresa e empresa de pequeno porte.

A autenticação realizada pela Junta Comercial é ato escritural de autenticação e regularidade do documento, requisito intrínseco de validade dos livros comerciais e das fichas escriturais.

\subsection{Processo de registro perante a junta comercial}

O processo de registro perante a Junta Comercial não é obrigatório, mas para que uma empresa possa funcionar legalmente no Brasil, é necessário que esteja registrada e inscrita em diversos órgãos federais, estaduais e municipais.

No âmbito federal, a empresa deve ser registrada na Junta Comercial para efeitos do Registro Mercantil constante do relatório do DNRC. Dependendo da atividade a ser exercida a empresa precisa também obter autorização para funcionamento.

Ao obter o registro na Junta a empresa fica automaticamente inscrita no Instituto Nacional de Seguridade Social, para fins de recolhimento das contribuições devidas a esse instituto pelas empresas e empregados. 
Depois de efetuado o registro é necessário que a empresa seja inscrita no Cadastro Geral de Contribuintes do Ministério da Fazenda, para o pagamento dos tributos e contribuições federais devidos.

Nesse caso, além da documentação sobre a empresa, é exigido como condição para a concessão da inscrição que o titular ou o sócio, ou empresas de que esses participem, não tenham qualquer pendência junto ao fisco federal, seja de tributos ou contribuições, seja de obrigações acessórias.

Concluídos o registro e a inscrição no âmbito federal, a empresa deve ser inscrita no cadastro fiscal da Secretaria de Fazenda do Estado, quando for contribuinte do Imposto sobre Circulação de Mercadoria - ICMS. Em diversos Estados, antes da concessão da inscrição, é feita uma vistoria no local onde a empresa será instalada.

Em relação ao município deve ser feita a inscrição junto ao órgão fazendário para fins de contribuição do Imposto Sobre Serviços - ISS, quando for contribuinte desse imposto.

A maioria dos Estados e Municípios condiciona a concessão da inscrição da empresa em seu cadastro fiscal à situação regular perante o fisco, como acontece no âmbito federal.

Finalmente, deve ser obtido junto ao órgão competente do município o Alvará de Funcionamento, que autoriza o exercício da atividade pretendida no local destinado à sede da empresa, à vista das disposições do Código de Posturas do Município.

Neste momento dependendo da atividade da empresa são efetuadas vistorias do órgão de controle sanitário do município e do corpo de bombeiros. Em caso de atividades de risco, como fábricas de fogos de artifício, atividades causadoras de poluição ambiental e outras, deve também ser obtida a autorização de outros órgãos.

\section{A ATIVIDADE EMPRESARIAL E AS CONSTITUIÇÕES BRASILEIRAS}

As primeiras Constituições Brasileiras influenciadas pelo liberalismo com o qual as Cartas da Independência de 1824 e Carta Republicana de1891 restringiam-se a estrutura e organização dos Estados. A atividade empresarial inicialmente foi vista como atividade eminentemente privada tutelada pelo Código Comercial de 1850 e desprovida de conteúdo consititucional.

Contudo, no início do século XX com o advento da Constituição Mexicana de 1914 e a Carta de Weimar de 1917, portadoras de um novo pensamento constitucional, as novas Constituições brasileiras apresentariam normas para além do pensamento liberal, mas também, disposições referentes à diretrizes jurídicas, econômicas, sociais e políticas do Estado. 
O Brasil seguiu esta nova tendência constititucionalista a partir da Carta de 1934, todas as demais de 1937, 1946, 1967 e 1988 consignaram normas e princípios sobre a ordem econômica.

A Constituição brasileira de 1967 estabelecia naquela época tratamento diferenciado ao capital nacional e ao capital estrangeiro, no sentido de proteger as empresas nacionais com benefícios que somente a estas seria atribuido pela legislação. Tal primado, atualmente seria extremamente controvertido, diante do fenômeno da globalização econômica e, principalmente, após o surgimento da Organização Mundial do Comércio (OMC) cuja meta do livre comércio internacional, no qual bens e capitais circulam de um Estado para outro, sem que se lhe possa criar barreiras, restrições ou discriminações. Tornaria impráticável atualmente a existência de tal dispositivo constitucional.

A Constituição brasileira de 1988 de modo diverso estabeleceu princípios estruturantes da ordem econômica que norteiam a edição e interpretação das leis infra-constitucionais, nomeadamente a legislação e o direito empresarial.

\subsection{Os pressupostos constitucionais do Direito Empresarial}

O regime empresarial estabelecido pela Teoria da Empresa prevista no Código Civil de 2002 trouxe um conjunto ordenado e cientifico de regras destinadas a reger a atividade empresarial pautado pelo Princípio Constitucional da legalidade (art. $5^{\circ}$ da CF). Isso significa que, todos os usos e práticas mercantis assentadas nas Juntas Comerciais, como toda as legislações ordinárias estão subordinadas à observância desses princípios.

Afirma Alfredo de Assis Gonçalves $\mathrm{Neto}^{3}$ que os princípios constitucionais, como sobre a ordem econômica plasmados na Constituição de 1988 devem ser não só respeitados pelas leis infra-constitucionais, mas também, tais princípios é que influem decisivamente no seu alcance e na sua interpretação. Aponta-se os Princípios Constitucionais que norteiam a atividade econômica, quais sejam:

I. Livre Iniciativa (Art. 1ํ, IV e Art. 170)

II. Liberdade de Associação (Art. 5ำ XVIII e XX)

III. Liberdade de Trabalho Ofício E Profissão (Art. 5ํㅡ. XIII e Art. 170, parágrafo único)

IV. Soberania Nacional ( Art. 1으, I e Art. 170, I)

V.Propriedade Privada dos Meios de Produção ( Art. 5으, XXII e Art. 170, II )

VI. Função social da Propriedade ( Art. 5, XXIII e Art. 170, III)

VII. Livre Concorrência ( Art. 173, parágrafo 4ํㅜ)

VIII. Defesa do Consumidor ( Art. 5 XXXII e Art. 170, V )

IX. Defesa do Meio Ambiente ( Art. 170, VI e Art. 225 )

X. Redução das Desigualdades Regionais e Sociais ( Art. 3oㅡ e Art. 170. Inciso VII )

XI. Busca do Pleno Emprego (Art. 170, VIII) 
XII. Tratamento Favorecido para Empresas de Pequeno Porte Constituidas sob as Leis Brasileiras e que tenham sua Sede s Administração no país (Art. 170, inciso IX)

Acrescente-se ainda as Emendas № 5 a 9 que suprimiram várias restrições que a Constituição de 88 impunha à iniciativa privada, quer seja eliminando o monopólio de empresas públicas, quer facultando ao setor privado a prestação de serviços públicos sob o regime de concessão ou permissão, desta forma ampliando a atividade econômica privada.

Os pressupostos constitucionais que norteiam da atividade econômica são orientados pelos princípios de direito econômico e do direito concorrêncial, são estes primados que os operadores do direito devem buscar para a interpretação e a aplicação do Código Comercial de 1850, bem como de toda a legislação que lhe é posterior.

\subsection{A proteção da Ordem Econômica e da Concorrência}

A Constituição Federa de 1988 estabeleceu mecanismos de amparo à liberdade de competição e iniciativa, visando coibir a prática empresarial em duas categorias: (i) infração da ordem econômica (ou abuso do poder econômico) e, (ii) concorrência desleal.

Em decorrência direta de norma Constitucional ${ }^{4}$ foi editada a Lei Antitruste e de infrações à Ordem Econômica, Lei n. 8.884/94 de 11 de junho de 1994, a qual em seu artigo $1^{\circ}$ ao apontar como sua finalidade a prevenção e a repressão às infrações contra a ordem econômica, expressamente consigna sua orientação pelos princpícios constitucionais, dentre os quais destaca: (i) Princípio da Liberdade de iniciativa, (ii) Princípio da Livre concorrência, (iii) Princípio da Função social da propriedade, (iv) Princípio da Defesa dos consumidores, e, (v) Princípio da Repressão ao abuso do poder econômico.

A aplicação adequada e eficaz da legislação antitrutes dependerá da assunção e da compreensão dos seus pincípios básicos, que orientaram quer a elaboração da lei, quer a sua aplicação, neste sentido João Bosco Leopodino da Fonseca ${ }^{5}$ elenca como princípios:

I. Princípio da liberdade do Comércio e Indústria garante aos particulares a faculdade de exercer as atividades correspondentes e essas noções, mas deixa à autoridade pública, como para todas as liberdades, o poder de submeter este exercício a limitações

II. Princípio da liberdade do Contratual - garante a autonomia da vontade. 
III. Princípio da Igualdade - garante a possibilidade de todos atuarem no mercado independentemente do seu tamanho estrutural

IV. Princípio da Não-discriminação - no que se refere a concorrência leva em conta a ação de participantes do mercado no sentido de, por medidas de elevação ou abaixamento de preços, impeçam o ingresso de possíveis participantes ou eliminem alguns que estejam compondo 0 mercado

V. Princípio da Transparência do Mercado - o funcionamento do mercado, em regime de concorrência tem como um de seus pressupostos básicos a lealdade que deve servir de parâmetro mensurador de todas as atitudes de todos os integrantes

VI. Princípio da Análise Econômica - As normas pertinentes à preservação do mercado não podem aplicarse em abstrato. Deve-se sempre proceder a uma análise do caso concreto, seguindo os parâmetros e os métodos da economia.

VII. Princípio da Regra da Razão - proíbe todos os contratos e combinações que acarretem uma desarrazoada e indevida restrição do comércio e do intercâmbio.

\section{A DEFESA DA CONCORRÊNCIA NO BRASIL}

O Direito da Concorrência no Brasil possui normas relativamente recentes ${ }^{6}$ editadas na última década do século XX, o que explica a ausência no país de uma "cultura concorrêncial" ou uma "cultura antitruste" 8 .

A legislação brasileira de defesa da concorrência foi em grande parte influênciada pela legislação norte-americana, principalmente na adoção terminológica de "mercado relevante", "posição dominante" e "abuso de poder econômico", dentre outros termos.

\subsection{Do abuso do poder econômico}

A Lei $n^{\circ}$ 8.884/94, que disciplina as Infrações à Ordem Econômica foi promulgada a partir dos ditames constitucionais de liberdade de iniciativa, livre concorrência, função social da propriedade, defesa dos consumidores e repressão ao abuso do poder econômico que norteiam a ordem econômica os quais estão estabelecidos no artigo 170 da Constituição Federal. 
Estabelecendo uma sistemática para caracterização da infração prevista na Lei ํㅡ 8.884/94, estabelece uma conjugação de dois dispositivos para sua caracterização:

(i) 0 artigo 20 - estabelece o objetivo ou os efeitos possíveis para a prática empresarial ilícita, que ao Estado, nomeadamente por meio do Conselho Administrativo de Defesa Econômica -CADE cumpre reprimir, em decorrência direta do disposto no artigo 173, $\S 4^{\circ}$ e artigo 170 , inciso IV da Constituição Federal de 1988;

(ii) 0 artigo 21 - estabelece de forma não exaustiva as diversas hipóteses de ocorrência das infrações a ordem econômica no que tange as ações dos agentes econômicos em seu relacionamento entre particulares (empresa $X$ empresa ou empresa $X$ consumidor). Nestes casos a parte prejudicada terá o direito de exigir no Poder Judiciário a suspensão de sua prática e a correspondente indenização pelos prejuízos, conforme prevê o artigo. 29 da Lei $8884 / 94^{9}$ e artigo 186 do Código Civil ${ }^{10}$.

Assim para a caracterização da infração a ordem econômica para atuação do CADE basta a comprovação dos efeitos considerados abusivos no artigo 20, e que, tenham por objeto ou possam produzir os seguintes efeitos ainda que não sejam alcançados: (i) limitar, falsearr ou de qualquer forma prejudicar a livre concorrência ou a livre iniciativa; (ii) dominar mercado relevante de bens ou serviços; (iii) aumentar arbitrariamente os lucros; e, (iv) exercer de forma abusiva posição dominante. Desta forma, para caracterização da infração contra a ordem econômica a prova de que alguém, agindo como acusado agiu, produziria ou poderia produzir os efeitos considerados abusivos pela lei, vale dizer: prejudicar a livre concorrência ou dominar mercado relevante de bens ou serviços deve ser submetido à análise do CADE (Art. 54, $\S 1^{\circ}$, da Lei ํo 8.884/94).

O artigo 20 da Lei no $8.884 / 94$ de forma clara estabelece a resposabilidade objetiva do agente econômico por atos que possa ser caracterizados como infração a ordem econômica. Desta maneira, o infrator será responsabilizado independente de ter agido com dolo ou culpa. A responsabilidade do agente econômico configurado como infrator decorre da simples causualidade material, sem se perquerir da existência de culpa, ou se, os eventuais efeitos tidos como infração alcaçaram ou não seus resultados. A responsabilidade objetiva tem previsão legal no Código de Defesa do Consumidor e no Código Civil brasileiro a teor do parágrafo único do artigo 927 que aponta que, haverá obrigação de reparar o dano, independentemente de culpa, nos casos especificados em lei, ou quando a atividade normalmente desenvolvida pelo autor do dano implicar, por sua natureza, risco para os direitos de outrem.

E por fim, a teor do artigo 20, para configurar a responsabilidade objetiva de um infrator por ato caracterizado como infração a ordem econômica, não é necessário que os efeitos danosos não tenham sido 
alcançados, basta apenas que 0 ato potencialmente lesivo tenha sido realizado. Exemplificando: se uma pessoa no intuito causar prejuizos a determinada empresa bancária que possui ações na bolsa de valores, espalha boatos no mercado sobre sua fragilidade financeira, tudo através de e-mail enviados ao Banco Central e aos diretores dos principais concorrêntes. Tal ato em sí já é caracterizado como infração a ordem ecnômica, independentemente dos efeitos terem sido alcançados, a teor do inciso I, do artigo 20 da Lei $\mathrm{n}^{\circ}$ $8.884 / 94$.

O artigo 21 da Lei no 8.884/94 elenca de forma não exaustiva em seus incisos as condutas que caracterizão uma infração da ordem econômica, além das hipóteses previstas no artigo 20 e seus insicos. Desta maneira, a parte que se julgar prejudicada pela ação de outro agente econômico, mesmo que não se configure exercício abusivo de posição dominante, caso em que o CADE deve atuar, poderá propor medida judicial para a cessação da infração cumulada com perdas e danos. No mesmo sentido está Fabio Ulhoa ao ponderar ainda que: "se a conduta não estiver elencada no Art. 21, mas mesmo assim se configurará infração se os objetivos forem os referidos no Art. 20 da Lei $n^{\circ} 8.884 / 94 " 11$.

\subsection{Do Conselho Administrativo De Defesa Econômica - CADE}

O Conselho Administrativo de Defesa Econômica - CADE na forma da Lei $\mathrm{n}^{\circ} \mathrm{8.884/94^{12 }}$ é um Tribunal Administrativo, sob a forma de autarquia, vinculado ao Ministério da Justiça, que na sua ação é auxiliado pela Secretaria de Direito Econômico - SDE com competência para a realização das averiguações preliminares e a instrução processo administrativo.

Ao CADE compete julgar os processos administrativos e atos de concentração instaurados perante a SDE para apuração de infração à ordem econômica. Essa atribuição the confere função judicante, suas decisões necessitam de execução judicial, não possuindo o CADE autonomia para exigir compulsoriamente o cumprimento de suas decisões.

As decisões do CADE constituiem título executivo extrajudicial, e comportam execução específica quanto impõem obrigação de fazer ou não fazer, podendo o juiz para isso decretar a intervenção na empresa. A medida judicial deverá ser promovida na Justiça Federal do Distrito Federal ou da sede ou domicílio do executado.

As decisões do CADE não admitem recurso na esfera administrativa, porém, pelo princípio da unicidade de jurisdição art. 5, inciso XXV da Carta Federal de 1988, que estabelece a lei não excluirá da apreciação do Poder Judiciário lesão ou ameaça de direito, poderá ela ser objeto de questionamento e até revisão pelo Poder Judiciário (cuja jusrisdição será a da Justiça Federal).

A SDE - Secretaria de Direito Econômico é órgão que auxilia o CADE na fase de instrução do processo. 


\subsection{Da natureza jurídica das decisões do CADE}

As decisões do CADE, enquanto autarquia vinculada ao Poder Executivo, se constituem em atos administrativos ${ }^{13}$. No momento em que 0 CADE prolata uma decisão administrativa estabelecendo uma multa ou, ainda, determinando a fusão de empresas em virtude de uma conduta lesiva a ordem econômica, está praticando um ato Administrativo, emanado de entidade componente da Administração Pública Indireta Federal.

\subsubsection{A questão do caráter vinculado ou discricionário do ato}

A questão de saber se a decisão prolatada pelo CADE se constitui num ato administrativo vinculado ou discricionário é de fundamental importância, para saber os limites que estão subordinados os membros do conselho em suas decisões (art. 42 a 51 da Lei no 8.884/94).

Contudo é controversa a questão de saber se este ato (decisão do CADE) é de caráter vinculado ${ }^{14}$ ou discricionário ${ }^{15}$, classificação de profunda importância para o controle que eventualmente seja exercido pelo Poder Judiciário.

Os atos discricionários emitidos pela Administração (ou os aspectos discricionários do ato emitido pela Administração) escapam do controle judicial.

O controle a ser exercido pelo Poder Judiciário, limita-se em verificar a legalidade do ato e se a Administração não ultrapassou os limites da discricionariedade. Ao contrário, sendo viculados os atos praticados pela Administração, ao Poder Judiciário é dado revê-los, de forma plena.

\section{técnica \\ 3.2.2 A questão dos conceitos indeterminados e da regulação}

A existência dos denominados conceitos jurídicos indeterminados ${ }^{16}$, em que pese a doutrinária contrária ${ }^{17}$, se faz presente em todos os ramos do direito, como por exemplo, no direito privado o conceito de bom pai de família, ou ainda, no direito público, o conceito de interesse coletivo, utilidade pública, como também, o conceito de dominação de mercados, prática monopolística, entre outros.

Portanto, conceitos jurídicos indeterminados seriam aqueles conceitos fluídos, vagos ou imprecisos utilizados pela lei para caracterizar determinadas situações ou estabelecer o comportamento a ser adotado pela Administração. Nessa hipótese, à Administração seria dado o poder de optar, livremente, por qualquer das soluções. 
Com acuidade Amanda Flávio de Oliveira, aborda o tema dos conceitos indeterminados, asseverando que "os conceitos são indeterminados só em abstrato, diante de um caso real, eles realizam-se ou não. Daí o seu caráter regrado ou vinculado" ${ }^{18}$.

Tanto quanto os conceitos jurídicos indeterminados, a regulação técnica, foi tradicionalmente, compreendida pela doutrina como um hipótese de poder discricionário da Administração, era a chamada "discricionariedade técnica" na qual a aplicação da lei pela Administração estava sujeita à avaliação de um aspecto técnico.

A doutrina mais recente prefere entender essa situação como uma atividade vinculada da Administração ${ }^{19}$.

\subsection{Princípios jurídico-administrativos aplicáveis no controle judicial das decisões do cade}

Os princípios jurídico-administrativos são formas de controle da discricionariedade das decisões emanadas pelo CADE, na exata medida em que, é por meio do reconhecimento da existência de princípios comuns aplicáveis às penas e às sanções administrativas que devam estar presentes nas decisões do CADE que se opera o controle judicia. Os principíos que são aplicáveis no controle das decisões são:

(i) Princípio da Razoabilidade ou Proporcionalidade - Assim os fatos que motivaram a atuação da Administração devem receber, por parte dela um tratamento proporcional à sua dimensão e significado.

(ii) Princípio da Legalidade - A Carta Federal impõe ao regime jurídico-administrativo, o princípio da legalidade, que garante que a ninguém será imposta uma obrigação (de fazer ou de não fazer) sem prévia cominação legal.

(iii) Princípio do Devido Processo Legal Assevera Daniel Ferreira que não apenas atinente às sanções, de qualquer índole, o princípio do devido processo legal, tem por escopo garantir, a quem quer que seja, o direito de contraditar, processual e materialmente, toda e qualquer atuação estatal tendente a despojá-lo de sua liberdade ou de seus bens - isto é, de tudo o que efetivamente a Constituição Federal vigente tratou de socorrer sob o manto "dos direito e garantias fundamentais." ${ }^{20}$ Como decorrentes deste princípio encontra-se o contraditório que significa a faculdade de manifestar o próprio ponto de vista ou argumentos ante aos fatos, documento, dentro da mais ampla possibilidade de defesa. 
A lei prevê as seguintes penas administrativas para os empresários condenados pela prática de infração à ordem econômica (Art. 23 e seguintes da Lei no 8.8884/94): Multa; Publicação pela imprensa do extrato da decisão condenatória; Proibição de contratar com o setor público ou com instituições financeira oficiais; Inscrição no Cadastro Nacional de Defesa do Consumidor; Recomendação de licenciamento obrigatório de Patente titularizada pelo infrator; Negativa de parcelamento de tributos ou cancelamento de benefício fiscal; bem como, a determinação de atos societários tais como cisão ou transferência de controles compulsórios.

\section{O CARÁTER ALTAMENTE INTERDISCIPLINAR DO DIREITO DE CONCORRÊNCIA}

As especificidades das questões concorrenciais ${ }^{21}$ envolvem uma enorme influência da Ciência Econômica na Ciência Jurídica, a análise das situações deverão necessariamente ser interdisciplinares. A repressão da concorrência desleal é feita em dois níveis:

(i) No Direito Penal a lei tipifica como crime: Publicar falsa afirmação em detrimento do concorrente, com objetivo de obter vantagem; empregar meio fraudulento para desviar, em seu proveito ou de terceiro, a clientela de um certo comerciante; dar ou prometer dinheiro a empregado do concorrente para que este proporcione vantagem, faltando a dever do emprego.

(ii) No Direito Civil, a repressão à concorrência desleal pode ter fundamento contratual ou extracontratual que gerará o dever de indenizar.

O Direito da concorrência, nos processos que eventualmente tenham após a decisão do CADE um desdobramento no Judiciário, requer do juiz um posicionamento e uma mentalidade distintos. Não se trata unicamente de se utilizar de peritos que forneçam subsídios econ6omicos para a elaboração da decisão. Como aponta Amanda Flávio de Oliveira, o Direito de Concorrência requer do Poder Judiciário uma visão diferenciada do Direito, partindo-se do fato de as decisões judiciais representam um custo para a sociedade, gerando efeitos externos, o juiz deve perceber o contexto global dos conflitos e a compreender que seus julgamentos interferem inevitavelmente em outras esferas de interesse, além daquelas que estão envolvidas diretamente no caso que the foi submetido ${ }^{22}$.

Diante dessa perspectiva, a postura do juiz deverá ir de encontro com a Lei de Introdução ao Código Civil, que estabelece que "na aplicação da lei o juiz atenderá aos fins sociais a que ela se dirige e às exigências do bem comum". Trata-se, acima de tudo, de: a) o juiz tomar consciência das implicações econômicas do caso que the é submetido; b) o juiz procurar se informar quanto a essas implicações, e: c) tê-las em conta quando da tomada de decisão ${ }^{23}$. 


\title{
ASSUMPTIONS OF CONSTITUTIONAL BUSINESS LAW: Analysis of business records and system of protection of competition.
}

\begin{abstract}
This paper discusses the business activity conducted by the Company or Private Entrepreneur as economic agent whose activity is regulated by government agencies, Boards of Trade, Mercantile National Department of Records and Administrative Council of Economic Defense. In this perspective, will be analyzed constitutional assumptions that guide the enterprise economic activity, wich underlie the competition defense systems.
\end{abstract}

Key-words: Antitrust Business Law. Economic Order.

\section{NOTAS}

1. Professor Permanente no Curso de Pós-Graduação Mestrado/Doutorado em Direito da Universidade Federal de Santa Catarina - UFSC. Doutor em Direito pela Universidade Federal do Paraná (UFPR). Mestre em Direito pela Universidade Clássica de Lisboa Portugal. Professor de Direito Comercial do Curso de Graduação em Direito da UFSC. Email: marcosw@ccj.ufsc.br.

2. PAKER, Amilcar Douglas. Direito Comercial - Origem \& Evolução. Curitiba: Juruá, 2002, p. 14

3. GONÇALVES NETO, Alfredo de Assis. Manual de Direito Comercial. Curitiba: Juruá, 2000, p. 60

4. Artigo 173 , parágrafo $4^{\circ}$ da CF. "A Lei reprimirá o abuso do poder econômico que vise a dominação dos mercados, à eliminação da concorrência e ao aumento arbitrários dos lucros".

5. FONSECA, João B. da Leopoldino. A lei de proteção da Concorrência. Forense: Rio de Janeiro, 1998, p 30.

6. O Decreto-Lei, de 18 de novembro de 1938, é considerado como o primeiro texto legal com a finalidade de coibir quaisquer formas de impedir a livre-concorrência, a sua elaboração decorria do artigo 141 da Carta Federal de 1937. Em 1945, é editado o Decreto-Lei 7.666/45 destinado a coibir atos contrários à ordem moral e econômica, criando a COMISSÃO ADMINISTRATIVA DE DEFESA ECONÔMICA. EM 1962, A LEI 4.137/62 significou uma evolução no da disciplina da concorr6encia no Brasil, seus dispositivos apresentavam uma sistemática como responsáveis por orientar o processo administrativo instaurados perante 0 novo CONSELHO ADMINISTRIVO DE DEFESA ECONÔMICA - CADE. Em 1994 a edição da Lei 8.884/94 reestrutura e transfoma o CADE em autarquia e the atribui maior efetividade na prevensão e repressão às infrações contra a ordem econômica.

7. Neste sentido ver Amanda Flávio de Oliveira: "Especificamente no Brasil, a própria história do país impediu que houvesse, por algum tempo, a necessidade de leis que regulamentassem questões concorrenciais." OLIVEIRA, Amanda Flávio de. O Direito da Concorrência e o Poder Judiciário. Forense: Rio de Janeiro, 2002, p. 13

8. Neste sentido ver: Laércio Farina "estamos em formação de uma cultura anti truste (...) A Cultura do CADE ou a cultura das questões antitruste no nosso país, embrionária que é, impõe um reforço e impões também a formação de uma cultura sobre a força que o órgão, o Conselho Administrativo de Defesa Econômica deva ter, de forma a elevá-lo à categoria de órgão efetivamente eficaz e reconhecido como tal, nos moldes da Federal Trade Comission nos Estado Unidos." FARINA, Laércio. Do Processo administrativo da natureza do ato. Revista do IBRAC, Sào Paulo, vo. 3, n. 6,pp 104, jun.1996

9. Art. 29. Os prejudicados, por si ou pelos legitimados do art. 82 da Lei no 8.078 , de 11 de setembro de 1990, poderão ingressar em juízo para, em defesa de seus interesses 
individuais ou individuais homogêneos, obter a cessação de práticas que constituam infração da ordem econômica, bem como o recebimento de indenização por perdas e danos sofridos, independentemente do processo administrativo, que não será suspenso em virtude do ajuizamento de ação.

10. Art. 186. Aquele que por ação ou omissão voluntária, negligência ou imprudência violar direito e causar dano a outrem, ainda que exclusivamente moral, comete ato ilícito.

11. Ver as seguintes obras: COELHO, Fábio Ulhoa. Manual de Direito Comercial. São Paulo : Saraiva, 2002, p. 20 ; COELHO, Fábio Ulhoa. Curso de Direito Comercial. Vol. I. São Paulo : Saraiva, 2002

12. Art. $3^{\circ} \mathrm{O}$ Conselho Administrativo de Defesa Econômica (Cade), órgão judicante com jurisdição em todo o território nacional, criado pela Lei oㅜ 4.137, de 10 de setembro de 1962, passa a se constituir em autarquia federal, vinculada ao Ministério da Justiça, com sede e foro no Distrito Federal, e atribuições previstas nesta lei.

13. "Ato administrativo é a manifestação de vontade do Estado ou de quem lhe faça as vezes, expedida em nível infralegal e para dar cumprimento à lei, sob regime de direito público e sujeito a controle de legitimidade por órgão jurisdicional, com a finalidade de criar situações jurídicas individuais ou controle para a forma destas." ARAUJO, Florivaldo Dutra de. Motivação e controle do ato administrativo. Belo Horizonte: Del Rey, 2002, p. 62

14. Atos Vinculados seriam os atos em que a Administração não detém qualquer liberdade para a sua decisão, em virtude de a lei Ter previamente tipificado o único comportamento possível diante do caso concreto.

15. Ato Discricionário são aqueles atos em que a Administração goza de certa liberdade para decidir, já que a lei envolvida no caso concreto deixou em aberto uma margem de apreciação que comporta algum subjetivismo.

16. Neste sentido: FERRAZ JÚNIOR, Tércio Sampaio. Discricionariedade nas Decisões do CADE sobre Atos de Concentração. Revista do IBRAC, São Paulo, vol. 4.n. 6, pp 87-89, s.d.

17. Em sentido contrário: GRAU, Eros Roberto. Poder Discricionário. Revista de Direito Público, São Paulo: n 93, p 114-21, jan./mar. 1990; DI PIETRO, Maria Sylvia Zanella. Discricionariedade Administrativa na Constituição de 1988. São Paulo: Atlas, 1988.

18. OLIVEIRA, Amanda Flávio de. O Direito da Concorrência e o Poder Judiciário. Rio de Janeiro: Forense, 2002, p. 69

19. OLIVEIRA, Amanda Flávio de. O Direito da Concorrência e o Poder Judiciário. Rio de Janeiro: Forense, 2002, p. 71

20. FERREIRA, Daniel. Sanções Administrativas. São Paulo: Malheiros Editores, 2001, p. 103

21. "No que se refere à interpretação, vê-se que há inumeráveis termos econômicos - com suas variantes de marketing e de informática - que precisam ser compreendidos e avaliados juridicamente, nem todos suficientemente conceituados pela legislação." BULGARELLI, Waldirio. Contratação de empresas e direito antitruste. $2^{\mathrm{a}}$ Ed., São Paulo, Editora Atlas, 1996, p. 126

22. OLIVEIRA, Amanda Flávio de. O Direito da Concorrência e o Poder Judiciário. Rio de Janeiro: Forense, 2002, p. 102-103

23. OLIVEIRA, Amanda Flávio de. Op. Cit. p. 110

\section{REFERÊNCIAS}

ARAUJO, Florivaldo Dutra de. Motivação e controle do ato administrativo. Belo Horizonte: Del Rey, 2002.

BULGARELLI, Waldirio. Contratação de empresas e direito antitruste. $2^{\mathrm{a}}$ Ed., São Paulo, Editora Atlas, 1996.

COELHO, Fábio Ulhoa. Manual de Direito Comercial. São Paulo: Saraiva, 2002.

COELHO, Fábio Ulhoa. Curso de Direito Comercial. Vol. I. São Paulo: Saraiva, 2002. 
DI PIETRO, Maria Sylvia Zanella. Discricionariedade Administrativa na Constituição de 1988. São Paulo: Atlas, 1988.

FARINA, Laércio. Do Processo administrativo da natureza do ato. Revista do IBRAC, São Paulo, vo. 3, n. 6,pp 104, jun.1996.

FERRAZ JÚNIOR, Tércio Sampaio. Discricionariedade nas Decisões do CADE sobre Atos de Concentração. Revista do IBRAC, São Paulo, vol. 4.n. 6.

FERREIRA, Daniel. Sanções Administrativas. São Paulo: Malheiros Editores, 2001.

FONSECA, João B. da Leopoldino. A lei de proteção da Concorrência. Forense: Rio de Janeiro, 1998.

GONÇALVES NETO, Alfredo de Assis. Manual de Direito Comercial. Curitiba: Juruá, 2000.

GRAU, Eros Roberto. Poder Discricionário. Revista de Direito Público, São Paulo: $n 93$.

OLIVEIRA, Amanda Flávio de. O Direito da Concorrência e o Poder Judiciário. Forense: Rio de Janeiro, 2002.

OLIVEIRA, Amanda Flávio de. O Direito da Concorrência e o Poder Judiciário. Rio de Janeiro: Forense, 2002.

PAKER, Amilcar Douglas. Direito Comercial - Origem \& Evolução. Curitiba: Juruá, 2002.

Recebido para publicação: 30/11/2011

Aceito para publicação: 22/12/2011 